\title{
Portugal in Ruins: From "Europe" to Crisis and Austerity
}

Samuel Weeks

Thomas Jefferson University, samuel.weeks@jefferson.edu

\section{Let us know how access to this document benefits you}

Follow this and additional works at: https://jdc.jefferson.edu/jchsfp

Part of the Political History Commons

\section{Recommended Citation}

Weeks, Samuel. "Portugal in Ruins: From 'Europe' to Crisis and Austerity."

Review of Radical Political Economics, Volume 51, Issue 2, May 2019, Pages 246-264.

This Article is brought to you for free and open access by the Jefferson Digital Commons. The Jefferson Digital Commons is a service of Thomas Jefferson University's Center for Teaching and Learning (CTL). The Commons is a showcase for Jefferson books and journals, peer-reviewed scholarly publications, unique historical collections from the University archives, and teaching tools. The Jefferson Digital Commons allows researchers and interested readers anywhere in the world to learn about and keep up to date with Jefferson scholarship. This article has been accepted for inclusion in College of Humanities and Sciences Faculty Papers by an authorized administrator of the Jefferson Digital Commons. For more information, please contact: JeffersonDigitalCommons@jefferson.edu. 
Review of Radical Political Economics

"Portugal in Ruins: From 'Europe' to Crisis and Austerity"

Samuel Weeks, M.A., Ph.D.

College of Humanities and Sciences

Thomas Jefferson University

samuel.weeks@jefferson.edu

This file is the pre-publication version. Here is the citation of the published article:

Weeks, Samuel

2019 'Portugal in Ruins: From 'Europe' to Crisis and Austerity." Review of Radical Political Economics 50(2):246-264.

https://doi.org/10.1177\%2F0486613418776693

https://journals.sagepub.com/doi/full/10.1177/0486613418776693 


\section{Review of Radical Political Economics}

\section{Portugal in Ruins: From "Europe" to Crisis and Austerity}

\begin{tabular}{|c|c|}
\hline Journal: & Review of Radical Political Economics \\
\hline Manuscript ID & RRPE-17-0134.R1 \\
\hline Manuscript Type: & Original Manuscript \\
\hline Keywords: & $\begin{array}{l}\text { European economies, heterodox political economy, economic } \\
\text { and financial crises, international monetary arrangements and } \\
\text { institutions }\end{array}$ \\
\hline \multirow[t]{2}{*}{$\begin{array}{r}\text { Jel Classifications: To view Jel } \\
\text { classifications, please click }<\text { a href= } \\
\text { 'http://www.aeaweb.org/jel/guide/jel.php' } \\
\text { target='_new' }><\text { b }>\text { here }</ \text { b }></ a>\text {.: }\end{array}$} & B51, F55, P16 \\
\hline & $\begin{array}{l}\text { Drawing from the tradition of heterodox political economy, this } \\
\text { article engages the analyses of Nicos Poulantzas, Perry } \\
\text { Anderson, João Ferreira do Aramal, and others to outline the } \\
\text { central politico-economic contours of post-Carnation Revolution } \\
\text { Portugal. Written in a narrative style, the account that follows } \\
\text { examines the effects of EEC accession, EU structural funding, } \\
\text { Common Market liberalization policies, and the euro currency. } \\
\text { The article posits the troika's } 2011 \text { "rescue" of the Portuguese } \\
\text { state - and the accompanying austerity measures - as having } \\
\text { roots in the post-1974 process of "Europeanization." In } \\
\text { historicizing the current political and economic predicament } \\
\text { facing Portugal, this analysis challenges the explanations for } \\
\text { this situation commonly offered by troika officials and the } \\
\text { business press. Furthermore, the article addresses how } \\
\text { longstanding divisions among factions of the Portuguese left and } \\
\text { center-left - which date from the beginning of the } \\
\text { Europeanization process - have become less acute since the } \\
\text { November } 2015 \text { formation of a center-left/left parliamentary } \\
\text { majority led by the Socialist Party. However, this unique three- } \\
\text { party "anti-austerity" formation has had a limited margin to } \\
\text { maneuver, given the continued power over domestic politics } \\
\text { exercised by the EU and international creditors. }\end{array}$ \\
\hline
\end{tabular}




\title{
Review of Radical Political Economics \\ "Portugal in Ruins: From 'Europe' to Crisis and Austerity"
}

\author{
The Great Lisbon Earthquake, which took place on the morning of All Saints' \\ Day in 1755 , destroyed the vast majority of buildings in this imperial capital and its \\ surrounding regions. Triggering a tsunami and a bout of untamable fires, the earthquake, \\ estimated to have been in the range of 8.5-9.0 M, caused a death toll estimated to be as \\ high as 100,000 people, thus making it one of the deadliest seismic events in recorded \\ history. Among the many buildings destroyed in Lisbon was the massive Carmo Convent, \\ a fourteenth-century gothic edifice built in the aftermath of a Portuguese victory against \\ invading Castilian forces. Unlike other structures in the post-earthquake period, however, \\ Carmo's main nave was never rebuilt - in part because of financial considerations and a \\ Romantic-era aesthetic appreciation of medieval ruins, but also because it served as a \\ reminder to lisboetas of the catastrophic destruction wrought by the tremor. Over two \\ hundred years later, history once again reverberated from this locale during Portugal's \\ leftist Carnation Revolution of 25 April 1974, as the convent complex housed the final \\ stronghold of Marcelo Caetano, the last head of the authoritarian Estado Novo regime, \\ and the security personnel who remained loyal to him. \\ The ruins of the Carmo Convent, which sit atop a hill near Lisbon's downtown, \\ now overlook the shopping and tourism districts of Chiado and Baixa. From this elevated \\ vantage point, one can observe today the aftermath of another calamity: a multiyear \\ economic downturn that has caused widespread unemployment, threatened social \\ stability, and stretched thin the country's safety net. Just as Carmo's ceilingless nave
}


continues to evoke a disaster of millennial proportions 265 years after the fact, the post2010 crisis and its myriad repercussions will likely mark Portugal for generations to come.

\section{Four Terrible Years}

In June of 2011, just two months after Portugal's request for an international bailout from the EU-ECB-IMF “troika," the recently elected Prime Minister Pedro Passos Coelho predicted that the following two years would be "terrible" for the country (Público 2011). Apparent now is that Passos Coelho was being overly optimistic in making this prediction. His forecast of a "terrible two years" turned into a terrible four years, a verdict echoed by many political commentators. Even with the 2015 defeat of his center-right coalition by a parliamentary left majority, few ways out of the country's disquiet seem to be in sight.

The former prime minister was hardly alone in his misplaced optimism; making buoyant economic predictions that do not become reality has ostensibly become as common in Portugal as football analysis. Whether made by the domestic or international business press, or government or troika officials, pronouncement after pronouncement have turned out to be consistently wrong. Given that the country's commercial and residential properties remain plastered with "for sale" and "to let" signs - especially those not located in the few areas in the country buoyed by tourism - it has become obvious that Passos Coelho's "two terrible years" will instead mark the beginning of an extended period of economic malaise.

The irony of Portugal missing its bailout targets was that Passos Coelho and his first finance minister, Vítor Gaspar, pledged initially to make more structural changes to 
the economy than those mandated by the troika. Indeed, few of the crisis-ridden peripheral Eurozone countries have kept to the bailout's terms as diligently as has Portugal. However, as the country's economy continues to stagnate - as it has for five of the past seven years - thousands of restaurants, cafés, civil-construction outfits, and retail shops have closed, due in part to a collapse in demand caused by troika-mandated salary and pension reductions, rent, and tax increases and an unemployment rate over ten percent. Scores of small businesses have ceased all operations, shedding thousands of jobs in their wake. These so-called "micro companies," which employ fewer than ten workers, make up 86 percent of all enterprises in Portugal and account for 40 percent of jobs in the private sector (OECD 2013; cited in Wise 2013). In such conditions, many working- and even middle-class families struggle to get by, afraid to spend and fearful that one or both household income earners will lose their jobs.

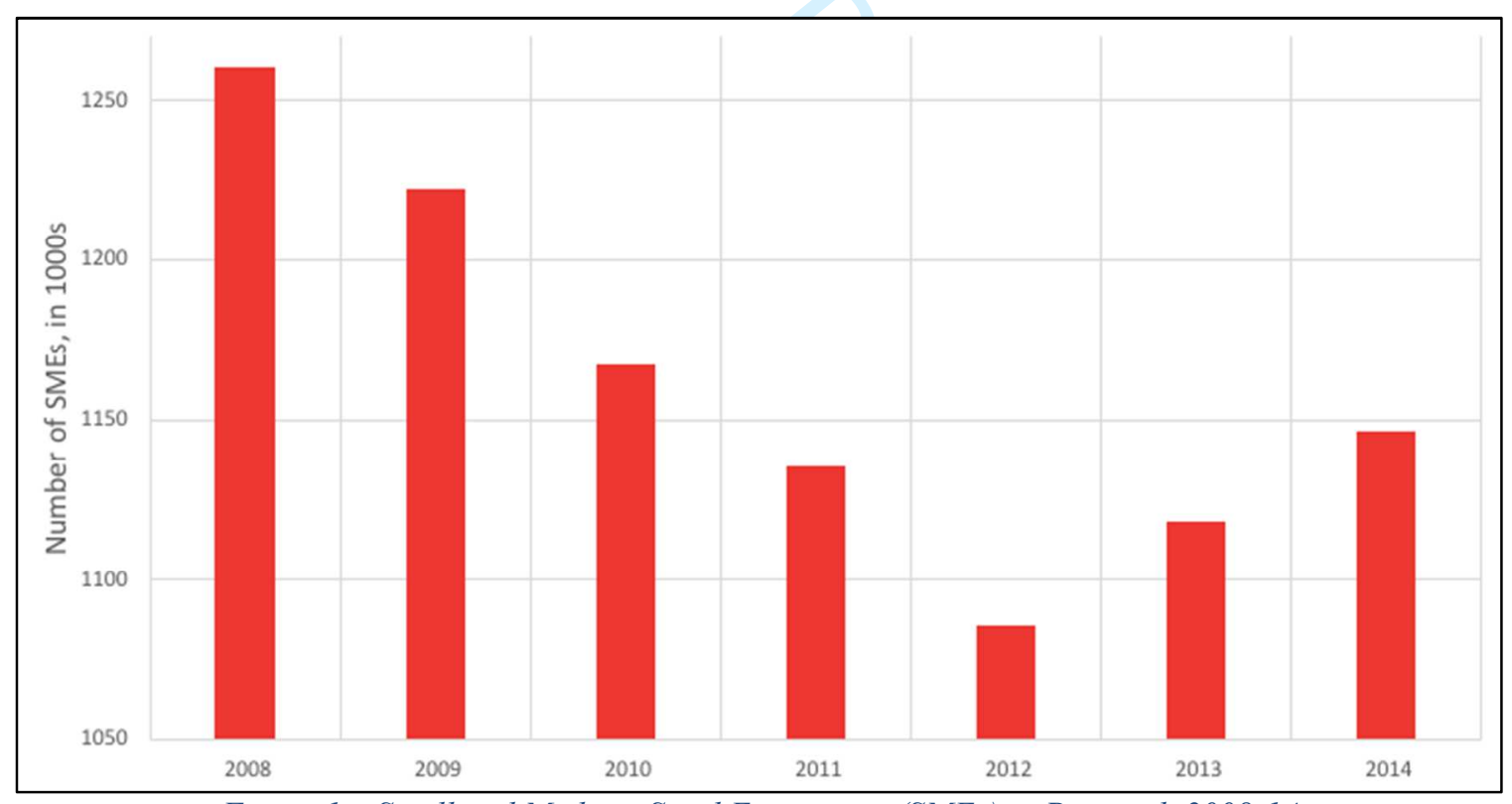

Figure 1-Small and Medium-Sized Enterprises (SMEs) in Portugal, 2008-14 (Data Source: Base de Dados Portugal Contemporâneo) 


\section{From Revolution to "Europe"}

To understand Portugal's current predicament, it is first necessary to analyze how Portuguese society emerged in the mid-1970s from the near 50-year dictatorship of António de Oliveira Salazar and how the resulting configuration metamorphosed as the country sought EEC membership during the early 1980s. The main point of reference in this trajectory is the Carnation Revolution of 25 April 1974, when junior officers in the Portuguese military overthrew the country's authoritarian government headed by Marcelo Caetano, who had assumed power shortly before Salazar's death in 1970. The ostensible grievance of these "Captains of April" - who referred to themselves as the Armed Forces Movement (MFA) - centered on the terms of their deployment to the prolonged and unwinnable colonial wars in Guinea-Bissau, Angola, and Mozambique. When overtures to Caetano via official channels were rebuffed, the young officers decided that the only way to end the wars in Africa was to offer Portugal a new political model, which they dubbed the "three Ds": democracy, development, and decolonization.

From mid-1974 to late 1975, the revolutionary period known as PREC (Processo Revolucionário em Curso), six provisional governments tried to strike a balance between the macroeconomic challenges facing Portugal and the immediate needs of its citizenry. The MFA program was ambitious, if not excessively bold; within weeks of 25 April 1974, the group had called for immediate elections and a "new political economy [to be] at the service of the Portuguese people, in particular the segments of the population who have previously been the least favored" (Gonçalves 1976). As expropriated property was nationalized and redistributed, wages and living standards increased significantly. These efforts centered on nationalizing the large family-controlled economic groups that 
dominated the domestic and colonial economies throughout the Salazar regime - in sectors as diverse as banking, insurance, oil refining, chemicals, food and beverages, steel, and shipbuilding (Baer and Leite 1992: 2). At the same time, MFA emissaries moved to end the three wars in Africa and initiate the process of handing over sovereignty to representatives of the liberation movements in the African colonies.

The speed with which these changes occurred, however, heightened tensions among the country's already antagonistic political forces, and continued economic instability caused great anguish among the population. Seemingly each political development during PREC instigated yet more rounds of upheaval and sporadic political violence. The most dramatic of these events was the failed coup attempt of 11 March 1975, led by General António de Spínola and the rightist elements in the police and armed forces loyal to him.

By November of 1975, tensions within the MFA had reached a breaking point; factions supporting a transition to socialism, namely under General Vasco Gonçalves and Major Otelo Saraiva de Carvalho, were outmaneuvered politically by a "moderate" bloc within the MFA called the Group of Nine. In February of 1976, these officers had gained control of the Council of the Revolution and won the backing of the three main bourgeois political parties: Mário Soares’s Socialist Party (PS), Francisco Sá Carneiro's center-right Democratic People's Party (predecessor to the PSD, the party of Pedro Passos Coelho), and Diogo Freitas do Amaral's conservative Social Democratic Center (currently the CDS-PP). In time, the remaining Marxist and far-left parties, including the Communist Party (PCP) and numerous Maoist and Trotskyist splinter organizations, were relegated to the margins of the political process. 
At this point, it is imperative to sketch out why Portugal's revolutionaries were unable to obtain more support for their experiments in popular organization and worker autonomy. While progressive MFA elements and parties on the radical left did win several important victories during PREC - namely in the areas of pensions, prices, wages, labor law, health care, land distribution, and housing - the elite and upper-middle classes, who had long counted on the support and protectionism of the Salazar government, were not challenged en masse in their positions of power within the country's core apparatuses (Morton 2011: 346).

While the reasons for the eventual ebb in Portugal's revolutionary experiment are many, a central factor points to the extent of foreign influence within the country's political economy. This state of affairs meant that powerful international entities, from large Western European and US banks and industrial groups to the Pentagon and CIA, were keen to scuttle PREC from the outset. Even the factions of the MFA that supported a transition to socialism were reluctant to contest the many foreign economic and military interests in the country. US military and NATO installations in both the Azores and the Lisbon metropolitan area were resolutely off limits, and the PREC-era nationalizations "irreversible conquests of the working class," according to the constitution - were to mostly skirt the firms in the country representing foreign capital, including those factories producing for Renault, Firestone, and Toyota. In a way similar to the situations in other Southern European countries, Portugal's economy of this period was defined by a significantly higher percentage of foreign capital than in the nations of Europe's core (Anderson 1962: 102; Poulantzas 1976: 47). These two limitations, characteristic of Portugal's dependence on capital and materiel from Western Europe and the US, 
translated into non-negotiable boundaries that were not to be crossed by the Portuguese revolutionaries.

The second principal constraint on the revolutionary process could be seen within the MFA itself. While its ranks did include cadres of committed revolutionaries, most members were career officers, whose commitment to the "three Ds" was contingent on the promise that most of the long-standing hierarchies in the military and state would be maintained. Moreover, the more conservative tendencies within the MFA viewed the armed forces as Portugal's lone guarantor of public order and national unity. Thus, the MFA, originating as it did within the military apparatus and largely following the logic and discipline of this structure, was never likely to lead any potential transition to socialism (Poulantzas 1976: 134-35).

The final limitation on the revolutionary process was the ideological and political fragmentation of Portugal's leftist and ultra-leftist protagonists. While there was no doubt a great deal of revolutionary sentiment during PREC, the outpouring of militant classconsciousness was unfocused enough that it never coalesced behind a single group or movement. The actions of the staunchly Marxist-Leninist PCP from this era are indicative of this tension and point to the party's numerous fluctuations in strategy, such as support for untimely and poorly organized strikes and condemnation for the era's more radical manifestations of collective organization and resistance. By failing to collaborate with the ultra-left factions of the MFA, the PCP was unable to guarantee state support for the PREC-era workers' councils and agricultural cooperatives that its partisans had organized, especially when these came under eventual attack from a newly emboldened right (Ramos Pinto 2013: 217). Likewise, while it did succeed in disbanding PIDE - 
Salazar's ruthless and hated secret police force - and sacking the most visible collaborationists in the media (through a process of saneamento, or purging), a fragmented left could not break up the remaining institutions that had long supported the dictatorship and the national oligopolies, including the gendarmes of the GNR and the PSP security police (Blackburn 1974: 12).

These partisan fractures on the left, in turn, enabled forces from the center-left to the Christian democratic right to take control of the democratization process and initiate the subsequent turn towards "Europe" and its institutions. In fact, this latter promise of joining the European community seemed to resonate most strongly with Portuguese voters of the era, a sentiment reflected in the Socialist campaign poster for the 1976 parliamentary elections: "Europe, with Us." As seen in the other democratic transitions in Southern Europe, enticing the electorate with an opportunity to join the European institutions was an implicit strategy used by political elites (such as the PS's Mário Soares) to ensure the centrality of liberal democracy and capitalism in post-revolutionary Portugal. From the point of view of Portuguese elites, it was imperative to enshrine these two parameters quickly such that any challenge from the far-left or the militant working classes could be deflected by a system amenable to bourgeois interests.

Lines of communication between the three mainstream parties and the European institutions date from as early as 1974. The European Commission (EC) of FrançoisXavier Ortoli provided revolutionary Portugal with limited economic assistance, but was only willing to begin negotiations for membership once safeguards for liberal democracy and capitalism were instituted (Gallagher 1979: 213). In 1976, Mário Soares, the first elected prime minister in the post-dictatorship era, steered Portugal to membership in the 
Council of Europe and began the country's application to join the EEC. Each of these steps, in turn, served to consolidate support within the country for a liberal and capitalist Portugal.

The EEC negotiations, however, proceeded slower than Soares and others expected. Due to the precarious economic situation, as Finn writes,

Western allies pressed Soares to accept an IMF austerity programme [in 1977] that rolled back revolutionary redistribution and hit popular living standards hard, imposing deep wage and public-spending cuts to reduce labour's share of national income from 62.5 per cent in 1976 to [just over] 45 per cent in 1979 (2017: 12; see figure 2).

Tellingly, the prospect of joining "Europe" obliged the Portuguese authorities to temper and reverse many of the remaining measures dating from the PREC period. Responding to foreign pressure, those responsible for amending the constitution in the 1980s sought to remove the more radical of its clauses, such as the government's ostensible commitment to collective models of agrarian reform. The most notable hurdle preventing a swift conclusion of entry negotiations, however, was the legacy of the PREC-era nationalizations of assets in important economic sectors.

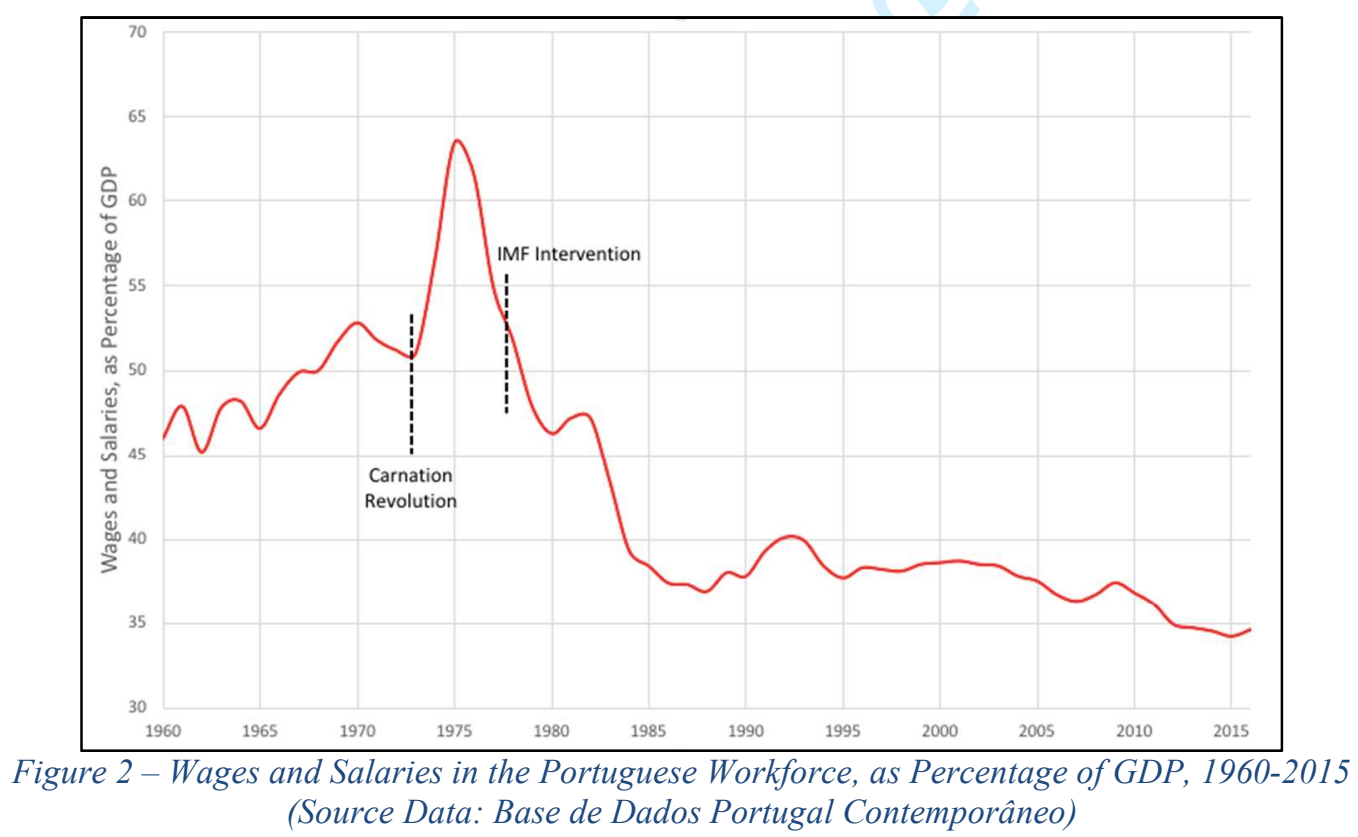


As a result, beginning in the mid-1980s, center-right Prime Minister Aníbal Cavaco Silva (PSD) mandated that the banks, insurance companies, media groups, industrial assets, and other entities nationalized during PREC start opening to private capital originating from domestic and foreign investors. A symbolic political move in this regard was to invite the families of the large oligopolies who had prospered greatly during the dictatorship - Melo, Champalimaud, and Espírito Santo, among others - to return to Portugal from their self-imposed exiles in locales such as London, Switzerland, Madrid, and Brazil and to repurchase controlling stakes in their old businesses. With these and other "obstacles" removed, the EEC approved Portugal's candidacy for membership to begin on 1 January 1986.

\section{Europe, with Us?}

Portugal became an EEC member during a time that this bloc of nations was undergoing a significant phase of integration. In 1986, the Single European Act was passed as the first revision to the Treaty of Rome in 30 years - followed in 1992 by the capital-friendly Maastricht Treaty, which called for the elimination of capital controls and the creation of the European Central Bank (ECB). Among Portugal's political and business elites, however, these developments were met with a degree of anxiety (Soares 2008: 463). Would Portugal's peripheral economy be able to meet the demands of liberalization at the same time that the government was ceding its sovereignty on monetary, budget, investment, and trade policies? That foreign goods and services would now be allowed greater access to Portugal's domestic market, traditionally more protected than those of its counterparts in the EEC core, meant that the country would be subject to unprecedented competitive pressures. 
In an attempt to mitigate these potential pitfalls, Cavaco Silva was able to secure a number of transfers of structural funds so that Portugal, in theory, would be better able to face the consequences of a liberalized European Single Market. The largest and most crucial of these initiatives was the Delors I Package of 1988. The considerable financial compensation of this act not only initiated a number of highly visible public-works projects, but also helped to further change the public's perception of "Europe" for the better. In the second half of the 1990s, EU structural funding amounted to 3.3 percent of GDP, leaving an undeniable mark in the country in the form of bridges, highways, and other infrastructure projects (Finn 2017: 15). As if to assuage the unease that Portugal would not be capable of meeting the challenges of EEC membership, these massive transfers of funds made manifestly clear the advantages of the country's integration into the European community (Soares 2007: 69-83).

As a result of liberalization measures and EEC (and later EU) adjustment funding, Portugal became an economic darling of Europe in the late 1980s, boasting low levels of unemployment and multiple years of GDP growth over four percent. Similar to previous booms during the Salazar years, a key driver for this growth was foreign direct investment into "light" manufacturing sectors - such as textiles, clothing, shoes, furniture, paper products, and food and beverages. This investment was again attracted to Portugal because of the country's newfound political stability and low labor costs in comparison to the rest of Western Europe (Baer and Leite 1992: 5).

An additional reason for the late-1980s expansion was sustained growth in the markets for commercial, retail, and financial services; these activities, however, corresponded to a marked rise in the levels of consumption and indebtedness of 
Portuguese households, catalyzed by declining interest rates, enhanced access to global capital markets, and a recently liberalized financial system - the latter the result of a 1989 EU directive directly transposed into Portuguese law (Rodrigues et al. 2016: 488-9). These tendencies intensified into the mid-1990s, just as Portugal took the remarkable leap of faith of signing up for membership in the fledgling Euro Monetary Union (EMU). By becoming a co-founder of the Eurozone, Portugal set a target date of 2002 to replace its escudo with a new currency, the euro.

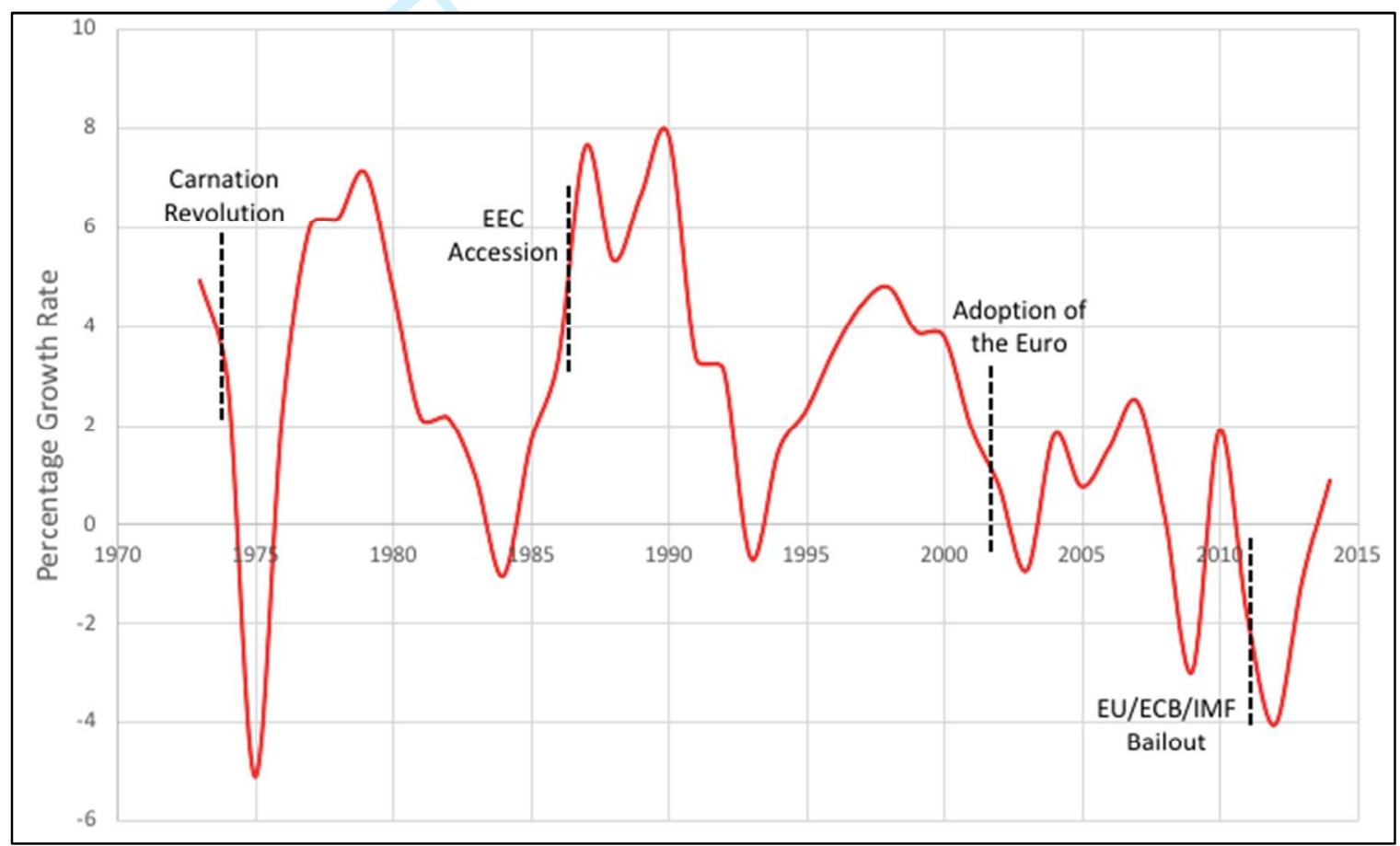

Figure 3 - Real Growth Rate, as Percentage of GDP, 1972-2014

(Source Data: Base de Dados Portugal Contemporâneo)

Joining this new monetary union brought with it a series of immediate advantages to Portugal. Central in this regard was stability and credibility for Portuguese state and private-sector borrowers, a standing premised on the country's membership within a major international currency zone. Interest rates dropped precipitously, which meant that the Portuguese no longer faced the punitively high rates that had prevailed in the past: down from 16 percent in the 1990s to around four percent in 2000s (Corkhill 2014: 43-8; 
see figure 6). The presumed low level of risk, and hence of defaulting, thus allowed money to flow from large German and French banks to borrowers in Portugal's public and private sectors. These changes instilled a newfound confidence in the country's politicians and business elites, who sought to shed their insular sensibilities inherited from years of isolation during the dictatorship and post-revolutionary periods.

The first warning signs, however, did not take long to appear. As credit flowed into the country, the borrowing levels of municipalities, businesses, and households increased dramatically, as did their debt levels. Thus, Portugal quickly became awash in borrowed money, a contemporary financialized version of the eighteenth-century Portuguese frigates that would return regularly from colonial Brazil laden with plundered gold. To quote Reis: in “the mid-1990s, Portugal's net foreign debt was close to zero. During the slump [of the 2000s], Portugal borrowed vast amounts from abroad, in one of the largest capital influxes the country has ever experienced" (2013: 151; see figure 7). Flush with this lent money secured from international financial markets, the Portuguese bought foreign goods and services in ever-increasing amounts, notably from its new EMU confrère Germany. In simple terms, German banks lent to Portugal so that Portugal could buy German exports; while Portugal borrowed and bought, Germany lent and sold. 


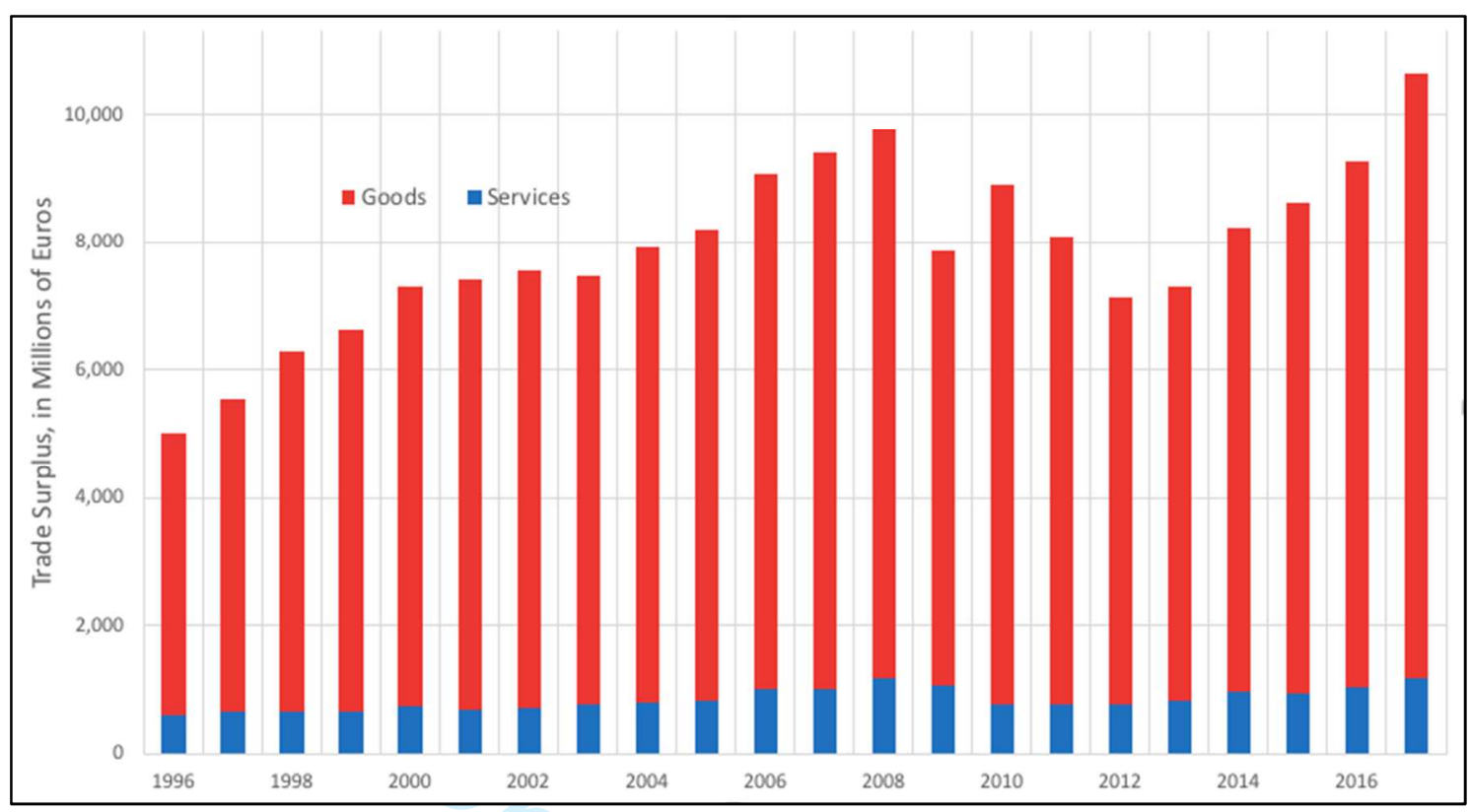

Figure 4 - Trade Surplus of German Goods and Services in Portugal, 1996-2017 (Source Data: Base de Dados Portugal Contemporâneo)

Trouble arose when Portuguese authorities realized that the country's central bank no longer possessed the monetary tools that it had used formerly to manage such disparities (Ferreira do Amaral 2006: 125-7). In the days of the escudo and the mark, any imbalance of payments would have resulted in an exchange-rate adjustment; the Portuguese currency would decrease in value, while the rates at which the country borrowed would rise. What was obvious, however, even in the early years of the Eurozone, was that the asymmetries between Portugal and Germany - countries with vastly different political economies, yet the same currency - were becoming increasingly exacerbated, rather than converging as the euro's promoters had hoped (Watkins 2013).

By the mid-2000s, the harsh realities of joining the single currency began to manifest themselves. Gone was the headiness of the early 1990s, when Portugal appeared to be catching up economically to its more affluent Northern European partners. What came instead was an extended period of anemic GDP growth - which averaged a mere 
0.6 percent from 2000 to 2007 , less than half the figure for the Eurozone as a whole

(2017: 16; see figure 3). Reis puts this in context:

Although Portugal never went through as steep a contraction as did the United States in the 1930s, its population today is poorer, relative to the start of the slump [in the early 2000], than Americans were at the end of the Great Depression or the Japanese after their "lost decade" (2013: 144).

The principle reason for this change of fortunes was Portugal's adoption of an excessively strong currency combined with the effects of trade liberalization on the country's manufacturing sector. Industries such as shoes, textiles, garments, and furniture, in which the typically smaller Portuguese firms held a comparative advantage under former trade agreements (e.g., EFTA), suffered due to a sharp downward pressure on wages, as countries with even lower labor costs from Central and Eastern Europe became EU member states and China joined the WTO.

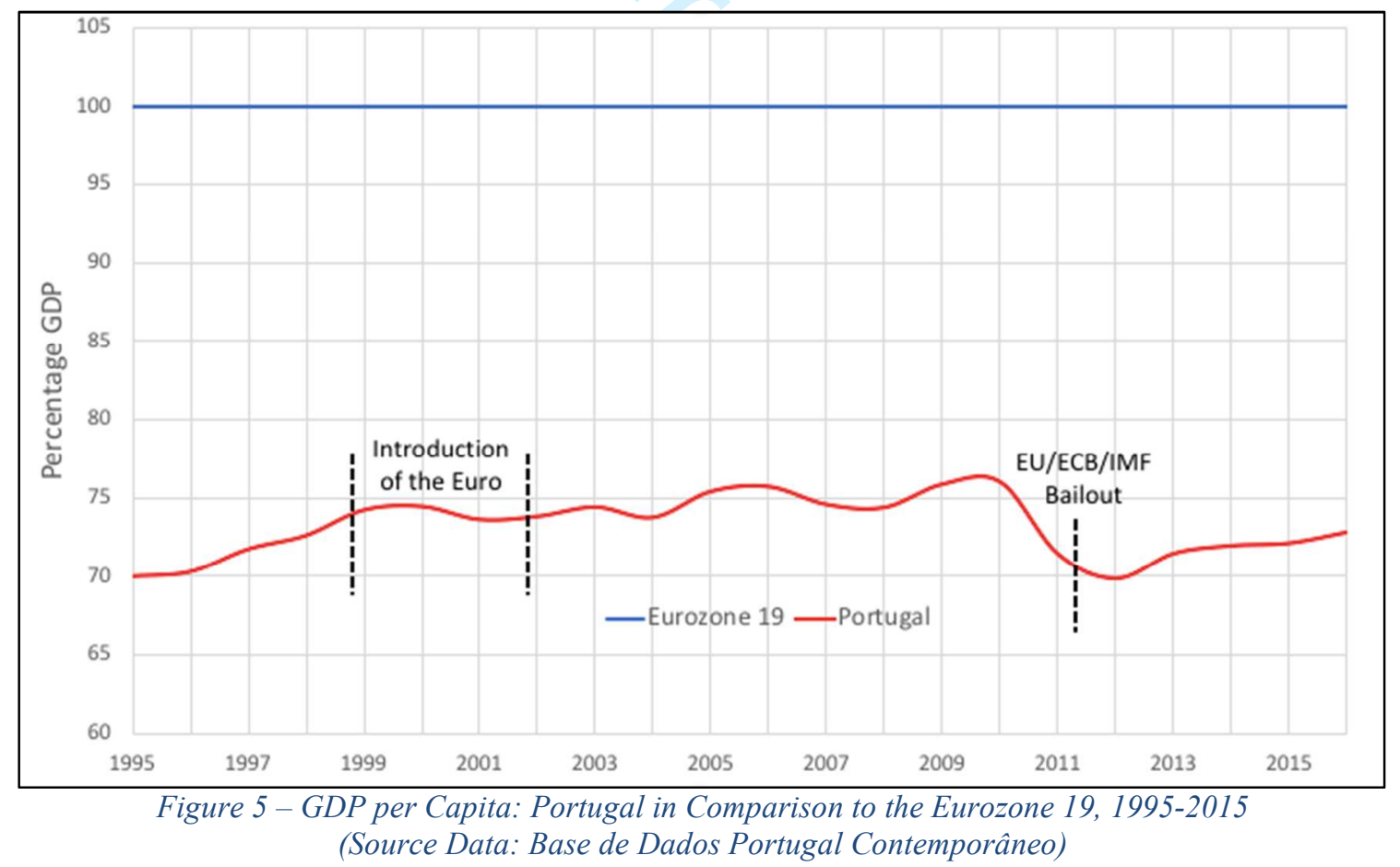

For the managers of big capital, when compared to Portugal, the new locales provided numerous advantages to companies seeking to relocate their manufacturing 
operations; in a race to the bottom, many of these countries offered hefty tax incentives to multinational corporations based in Northern Europe, in addition to giving them access to millions of similarly qualified yet more inexpensive workers (Meek 2017). Among the EU-15, Portugal was undoubtedly one of the most affected by this decamping of companies to points east. A corollary to these developments that compounded the negative effects for Portugal was heightened competition from the new member states for EU structural funds similar to the Delors I Package of 1988. In the wake of EU expansion and global-trade liberalization, Portugal was clearly being left in a difficult spot.

Starting in 2002, a succession of three governments in as many years - including a short-lived term for former Maoist José Manuel Durão Barroso (PSD), who was able to bow out of a contentious national political scene by becoming president of the European Commission (and later a "non-executive chairman" at Goldman Sachs) - aggravated the country's increasingly precarious economic situation. Again, the chief culprits for this downturn were the loss of manufacturing firms to overseas competition and a decrease in the domestic consumption that had been a leading motor for Portugal's economy since the 1990s. To make up for the subsequent loss of activity and employment in the manufacturing sector, successive governments (with EU abetment and financing) spent heavily on infrastructure and grands projets such as highways, airports, cultural facilities, football stadiums, and expansions to the metro systems in Lisbon and Porto, Portugal's second city.

However, such spending did little to reverse the trend towards stagnation in a context of global trade liberalization and the loss of Portugal's "competitiveness" as a country of relatively low labor costs for manufacturing. Not having the monetary tools, 
such as devaluing the escudo, to boost exports and redress the growing trade imbalances with its EMU partners made matters worse. As a Eurozone country, Portugal had instead become reliant on the actions of an ECB dominated by the austerity-minded German Ministry of Finance (which in turn receives support from like-minded homologues in the Netherlands, Austria, and Finland). Gone was its ability to formulate and execute monetary policies, such as setting the rates of exchange - a function that was now undertaken solely by the ECB executive board for all the countries in Eurozone (de Freitas 2017: 412). By adopting a strong currency with low interest rates, while being witness to a new phase of deindustrialization, this "Europeanized" Portugal all but ensured that the price to be paid at a time of crisis would be high.

\section{Crisis and Austerity}

Even as recent pro-austerity discourses make it seem otherwise, the Portuguese government was until 2010 never short of lenders willing to finance its spending. While creditors at one point lent money to Portugal at similar rates as they did to Germany, come late 2010, this inexpensive and readily available financing had evaporated - at which point the Portuguese found themselves stuck with an unaffordable currency and seemingly unpayable debts, in euros, to large non-resident investors. In the formulation of Rodrigues et al.: "while the semi-peripheral States of the Eurozone [such as Portugal] appeared to have borrowed in a domestic currency at very low interest rates, it is as if they had in fact borrowed in a foreign currency over which they had no control" (2016: 494). As early as the autumn of 2008, the global financial crisis originating in US realestate markets had begun to aggravate Portugal's teetering economic situation. In the wake of the collapse of Lehman Brothers, foreign money became more and more difficult 
to come by in Portugal, as fewer and fewer creditors were willing to finance the government's spending obligations at anything less than usurious interest rates.

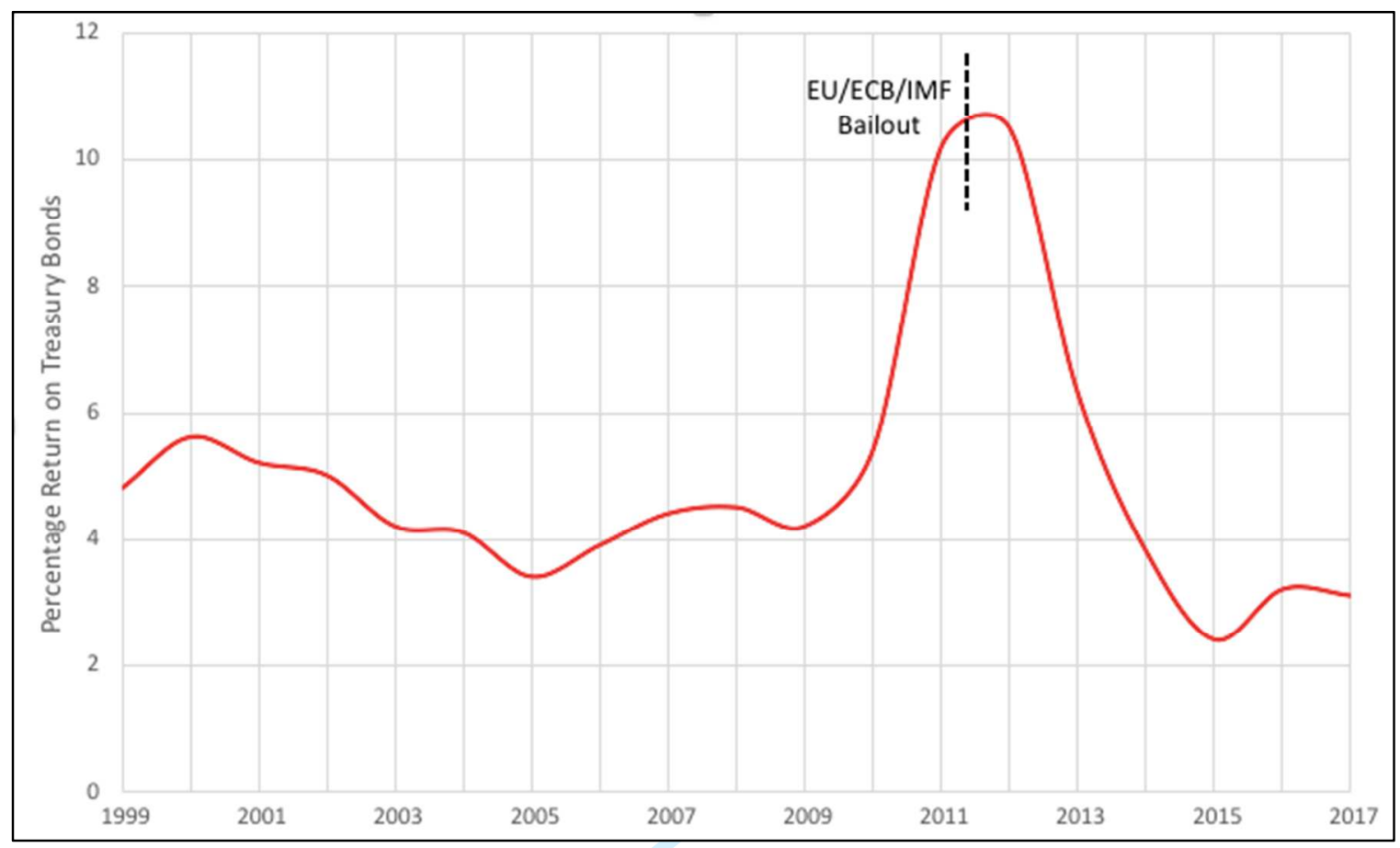

Figure 6-Return Rate on Portuguese 10-Year Treasury Bonds

(Source Data: Base de Dados Portugal Contemporâneo)

Unlike the situations facing Ireland and Spain, there was far less real-estate speculation in Portugal and little property "bubble" to burst. In contrast to Greece, levels of tax evasion and sovereign debt were never as dramatic, and highly centralized Portugal has few of the regional cleavages that make governing so difficult in Spain. What makes the Portuguese case different is that Portugal - unlike its Irish, Spanish, and Greek counterparts - did not experience a period of sustained growth, increases in worker productivity, or financial euphoria in the years leading up to the global crash (Reis 2013: 150). Neither were there any of the booms in the IT, construction, and tourism sectors as seen in Ireland, Spain, and Greece during the 2000s. In Portugal, financial turbulence especially during 2010 and 2011 - thus merely hastened an economic decline that was all 
too evident before the crisis and, accordingly, caused debt levels in the public and private sectors to balloon.

At this time, as if tensions within the Eurozone were not obvious enough, the contradictions between the economies of its core and periphery had become particularly stark. In Germany during the first half of the 2000s, internal devaluations of labor costs and measures to ensure wage stagnation - dubbed necessary labor-market "reform" by the business press - allowed Berlin to run increasingly large budget surpluses, which in turn exacerbated the account deficits of countries on the Eurozone periphery (Anderson 2009: 11-12). Thus, without significant increases to wages and consumption in Germany and elsewhere in the Eurozone core, countries such as Portugal continue to suffer problems of "competitiveness," whose only "acceptable" recourse to date has been excessively stiff austerity measures and harsh cuts to wages and pensions (de Freitas 2017: 427). Of course, such measures stifle macroeconomic growth and perversely have caused overall debt levels to rise significantly, as has been the case in the three Eurozone countries that have accepted "rescue packages" from the troika.

Yet again, these difficulties were magnified by the seeming lack of alternatives (pace Mrs. Thatcher). At the EU level, consensus among member states in support of a coordinated response was noticeably absent, as the Eurozone did not possess the mechanisms necessary to manage the political and economic integration that should come with monetary integration, particularly during moments of crisis. Furthermore, in a way that few could have imagined in the late 1990s, when Portugal signed on as co-founder of the Eurozone, the common currency had instead become one of the most divisive forces in Europe at the end of the 2000s (Delanty 2014: 213). What began as a bold experiment 
to form a multi-nation currency at the continental level had now become a chief source of division. For Portugal, the delusion behind its adoption of the euro was now plain to see. By late 2009, as the US sub-prime mortgage crisis spread to Europe, it was clear that Portugal was in an extremely difficult position. The country's economy experienced no growth in 2008 and suffered a 2.5 percent GDP contraction in 2009 (see figure 3). The already grim economic forecasts for Portugal meant that the crisis was bound to have an even more devastating impact than in other Eurozone countries. The situation worsened significantly in early 2010, when the Greek government could no longer secure credit in the markets, as interest rates for its sovereign debt had risen to levels deemed unsustainable. By that May, Greece was forced to request a financial "rescue" from the EU-ECB-IMF troika.

Meanwhile, Portugal's budget deficit surpassed 10 percent (see figure 9), while the government's gross financial liabilities to foreign creditors spiked from 60 percent of GDP in 2000 to 103 percent by 2012. The resulting combination of weak growth, little monetary flexibility, and severe imbalances within the EMU led Portugal's creditors to charge progressively wider spreads on the country's debt (see figure 6). In the words of Rodrigues et al.: "the growing dependence and therefore vulnerability to international finance partially contributed to the financial stress observed [in Portugal] in the immediate aftermath of the international crisis" (2016: 494). When Ireland became the second Eurozone country to receive a bailout in November of 2010, the prospect of Portugal following suit was a foregone conclusion. 


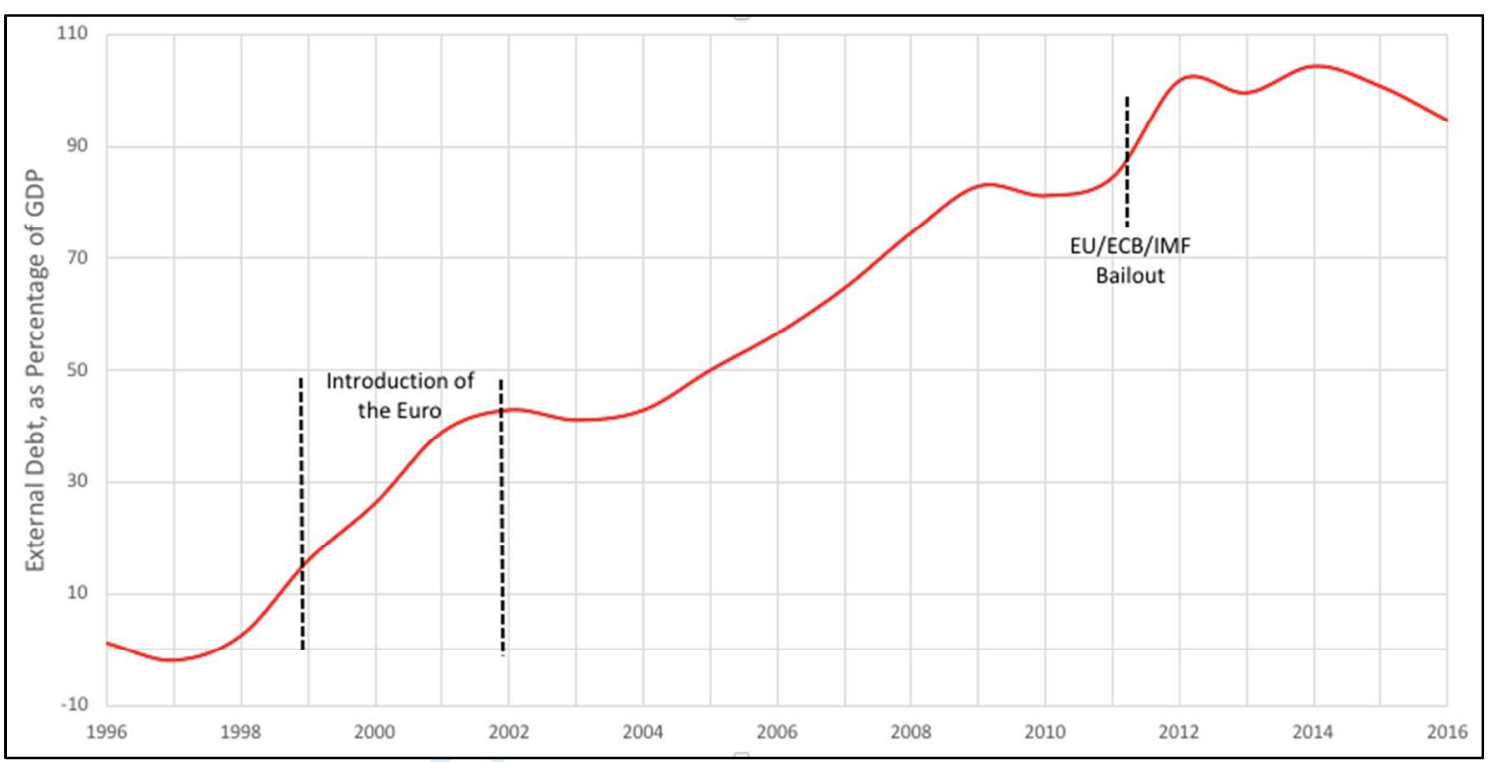

Figure 7 - Portuguese External Debt, as Percentage of GDP, 1996-2016 (Source Data: Base de Dados Portugal Contemporâneo)

Indeed, in April of 2011, after multiple months during which interest rates on Portuguese sovereign debt stood at eight percent or higher, Prime Minister José Sócrates (PS) was left with few options save the politically desperate appeal to the troika for a financial "rescue package." As if on cue, Sócrates's government collapsed quickly thereafter and was later defeated in the early June parliamentary elections by a centerright PSD/CDS-PP coalition led by Pedro Passos Coelho. Referred to as a "lifeline" by the business press, Portugal's bailout was something more akin to a pair of concrete shoes. The government was now forced to implement a litany of troika "crisis management" measures, similar to those imposed on Greece and Ireland: a "six pack" of severe macroeconomic policies, the "Euro Plus Pact," the "Fiscal Compact," the Orwellian-inflected "European Semester," and so on (Watkins 2014: 15).

Couched in Brussels' neoliberal legalese, these measures embraced an overarching objective, namely to provoke "structural adjustment" by combining cuts in wages with efforts to defund public services. In terms of reducing costs, the troika's 
memorandum with the Portuguese authorities detailed significant cutbacks in government transfers to municipalities and state-owned enterprises, as well as widespread reductions in the areas of education, health care, transport, pensions, and social services. The retirement age was increased to 66 . Other "savings" are expected to come from the total privatization of a number of existing public-private ventures and the sale of state-owned firms in key sectors such as transport, communications, and energy. To be phased out as well are the government's special rights in the country's largest companies, its so-called "golden shares," and four public holidays hitherto granted to Portuguese citizens. On the side of government receipts, the troika mandated the introduction of highly regressive excise charges and user fees, the elimination of income-tax deductions, and increases to property taxation and VAT rates - already some of the highest in Europe.

According to initial forecasts, made after the Sócrates government signed its 2011 bailout agreement with the troika, the economy should have restarted growth by 2013 . Instead, projections of the "fiscal consolidation" that austerity was supposed to deliver proved to be wildly optimistic. Instead of 2013 being the light at the end of the neoliberal tunnel, the economy that year promptly contracted another 2.3 percent (European Commission 2013: 3; see figure 3), due to the combined effects of a deeper-thanexpected downturn in Europe (particularly in Spain), a 1.1-billion euro bailout of the Madeira autonomous government, and a Portuguese high-court ruling in April that deemed a number of the troika-mandated austerity measures to be in breach of the country's constitution. These unconstitutional measures included a drastic reduction in state pensions and public-sector pay, as well as deep cuts in employee sickness and unemployment benefits. While such a ruling (the second in as many years) - one based 
on a constitutional mandate for equal, progressive, and non-discriminatory budget measures - was a formidable exercise of sovereignty in an era of fiat governance from Brussels, Berlin, Frankfurt, and Washington, it forced the Portuguese prime minister to look for alternative sources of revenue in order to reduce the budget deficit, including his desperate proposal for a 30-percent increase in income-tax rates.

In the face of a debilitating crisis, a punishing program of austerity and repeatedly fanciful forecasts by the troika as to the depth and duration of the downturn, it seemed probable that many of the austerity measures in Portugal would signal permanent retrenchment. The combination of substantial cuts in benefits, direct and indirect tax increases, waves of bankruptcies, and mass job losses have resulted in steadily rising hardship among large sections of the working and middle classes, many of whom now fall into the ranks of the "new poor" (Petmesidou and Guillén 2014: 302). The impact of these developments has been immense; in many families, grandparents with pensions have become the sole means of support to their grandchildren and unemployed sons and daughters. Just as alarming are the rising levels of child poverty and socio-economic inequality, which have increased in an unprecedentedly upward trend (Wise 2013). As a result of this fragile economic situation, Portugal's social safety net is under considerable stress, which has been the cause for much alarm among the country's religious organizations, charities, leftist parties, and two large trade-union confederations.

\section{From Division to Rapprochement}

Until recently, Portugal's system of alternating center-left and center-right governments had been able to manage most of the political consequences stemming from the post-2008 downturn. Notwithstanding high unemployment figures, continued 
economic stagnation, and deep cuts to public spending, the ritual of ousting an incumbent government has in Portugal - as it has in Spain, France, the United Kingdom, and Ireland - served as an outlet for the profound discontent harbored by voters. Akin to elsewhere in Europe, however, this process in Portugal looked to have reached an impasse in the run up to the 2015 legislative election. The two largest parties in the country - the center-left Socialists (PS) and the center-right Social Democrats (PSD) - have signed the troika's "memorandum of understanding," thus making their economic programs more alike than different. As a result, it was obvious that PS and PSD would offer voters little choice beyond who is to fill the suit representing Portugal as it stands pleadingly before its international creditors.

Nowhere was this malaise more apparent than in the immediate outcome of the October 2015 legislative elections. Despite the years of punishing austerity, the ruling center-right PSD/CDS-PP coalition - christened "Portugal Ahead" - came in first with 39 percent of the ballots cast, even as the two parties lost their combined absolute majority in parliament. Initially, the right-leaning national and international press hailed the coalition's "victory" as a vote of confidence for the continuation of austerity, or "fiscal consolidation" as its proponents refer to it. "The overwhelming opinion in the past two years was that the government would lose because you could not win with austerity measures," Miguel Poiares Maduro, a PSD minister, told the New York Times. "But I think we've now allowed people to see that their sacrifices made sense. I think the Portuguese people have understood that austerity was not a choice, but a necessity that we had to go through" (cited in Minder 2015). 
This narrative - which prompted PSD leader Passos Coelho to declare victory and begin forming a government - lasted hardly a news cycle before it became obvious that PS leader António Costa would not join a German-style "grand coalition” led by "Portugal Ahead." Moreover, Costa and party elder Mário Soares (now deceased) feared that PS support for a PSD/CDS-PP coalition would provoke an irrevocable split within its ranks, which might doom the Socialists to a fate similar to Greece's now-moribund center-left PASOK.

Allegations of opportunism aside, Costa was buoyed by the fact that Portugal's three main parties of the center-left and left - the Socialists (PS), the Communists (PCP), and the Left Bloc (Bloco de Esquerda, or BE) - saw their aggregate vote total increase by 20 percent and together could constitute a majority in parliament. Shortly after the election, Costa - a former mayor of Lisbon - began discussions with the leaders of the PCP and BE on a possible center-left/left parliamentary bloc, thus taking up an idea that the BE had proposed during the campaign. In the words of Finn:

Catarina Martins [leader of BE] had already indicated... that the Bloc would be willing to give external support to a PS government if it committed itself to a package of reforms to alleviate the social crisis. The PCP [Secretary-General] Jerónimo de Sousa had also signalled his party's readiness to discuss an arrangement (2017: 26).

Costa's opponents in "Portugal Ahead" and the media responded to such moves - similar to what the PS had done previously with parties of the center-right - with incredulity and derision. Luís Marques Mendes, a former PSD leader, reckoned that any accord between the Socialists and the parties to its left would mean political "suicide" for both Costa and the PS (Azevedo 2015). 


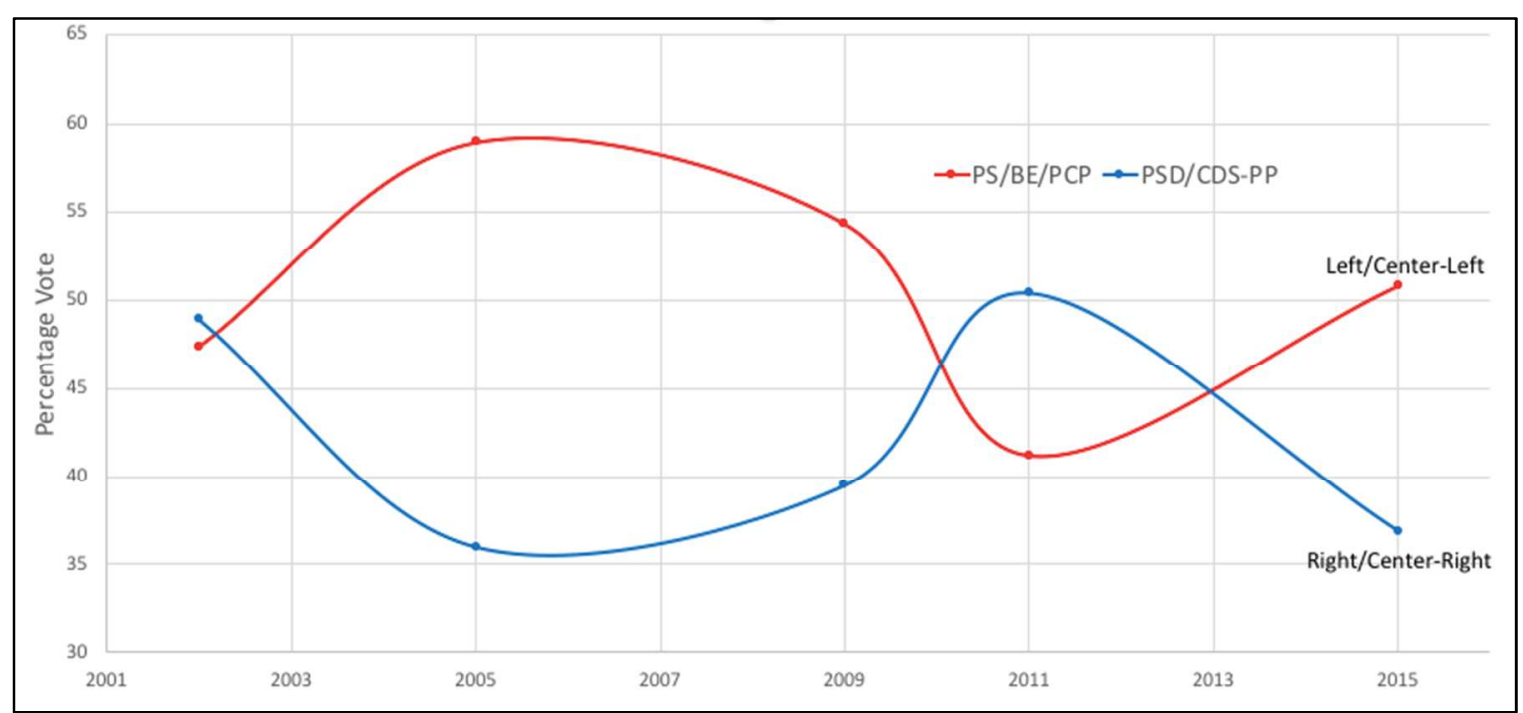

Figure 8 - Portuguese Legislative Election Results, 2002-15

(Source Data: Portal do Eleitor)

This widespread skepticism at the possibility of a center-left/left government in Portugal was not without merit. Historic divisions within the Portuguese left predate the debt crisis of recent years, as does its fragmentation on geographic, social, and political grounds. Such competing ideologies of the left in Portugal - social democracy, Third Way, and western and orthodox Marxism to name the primary ones - means that supporters are scattered across no fewer than five different party formations. These disjunctures have traditionally rendered coalition building on the left a Herculean task. Why would anyone think that this time would be different?

Hoping to stoke division and mistrust among the budding coalition, the media and the political right intensified their barrage of threats. Paulo Portas, Passos Coelho's deputy prime minister, entered the fray, claiming that any possible accord would be “politically illegitimate” (Wise 2015). Yet these empty condemnations were ultimately to no avail. After weeks of acrimonious negotiations - during which the Communists and the Left Bloc became obliged to drop their more radical positions, such as unilateral debt renegotiation and Portugal's withdrawal from NATO - Costa announced that the PCP 
and BE had agreed to support a government led by PS, ostensibly bridging a divide that dated from the PREC era of the mid-1970s. With characteristic rhetorical flourish, Costa claimed that the new coalition had torn down the "last remnants of the Berlin Wall" (cited in Marujo 2015).

Naturally, this surprising, even historic, feat of the Portuguese political system proved too democratic for some, beginning with Cavaco Silva (PSD), the then-President of the Republic. In his first address after the "accord of the left" was announced, a speech criticized even by his political allies, Cavaco drew the red lines for the new partners. Similar to during the PREC period, when powerful interests ensured that foreign businesses and military installations would be insulated from most revolutionary zeal, the president stated that he could (begrudgingly) accept a PS-led government only if PCP and $\mathrm{BE}$ removed from their programs any mention of Portugal renegotiating its debts or leaving the Eurozone or NATO. Condemnation of this anti-democratic gesture ensued almost immediately. To quote columnist Sérgio Ferreira Borges: "there are more than a million voters [who cast ballots for PCP and BE] whose voice will not be considered... By excluding the left, Cavaco Silva has provoked a terrible shockwave between the two bodies of sovereignty, the Presidency, and the Parliament" (2015).

The fervor with which Ferreira Borges and others denounced the president's posturing makes it seem as if such anti-democratic moves were rare in contemporary Portugal. Hardly. In fact, one can detect a logic to these maneuvers, given the frequency with which they occur. Take, for example, the 2016 state budget, the first to be proposed by the PS-led government. This included several measures considered sensible and long overdue for a country that still has not recovered its pre-crisis level of economic activity: 
reverse wage cuts, incentivize growth, fund research and development, and spur job creation. One might think that the head of state would proceed to present this draft budget to the public, but not in countries on the Eurozone periphery that were forced to drink from the troika's poisoned chalice. Rather, before being brought to a vote in parliament, state budgets in Portugal must be vetted by EU and IMF technocrats as well as by "the markets," that nebulous yet omnipresent authority most Portuguese politicians heed with an interest that they do not extend to their own electorate.

That the PS-led government's initial 2016 budget did not meet the troika's immediate approval resulted in the near obligatory market reaction when an event is not to the liking of international creditors: the Portuguese stock exchange tumbles multiple percentage points, while the country's bond yields spike. In what has become common during moments of "instability" in Europe, EU officials, international finance organizations, and large banks respond with a deluge of well-worn statements, rumors, and threats. Typifying the troika's rhetoric was German Minister of Finance Wolfgang Schäuble, who wasted no time in wagging his figure at the Portuguese as if they were a room of unruly pupils: "Portugal has to be well aware [bem ciente] that it alone can disrupt markets" (cited in Guerreiro 2016). Yet again, a normal political occurrence - in this case, the simple presentation of a budget by a new government with a mandate for change - proved too alarming for the creditors of the Portuguese state.

As the summer of 2016 approached, further confrontations between the PS-led government and the EU seemed inevitable. Once again, Portugal found itself in the crosshairs of the European Commission - this time, for its annual public deficit of greater than 3 percent (see figure 9). In light of Portugal's continued "non-compliance" with the 
budgetary targets outlined in the Maastricht Treaty, the Commission threatened to levy a substantial fine that the Portuguese government could ill afford.

And yet, in a way unseen since the mid-1990s, Portugal found its sails filled by the winds of external geopolitical developments. Throughout the spring of 2016, Mariano Rajoy - Spain's normally austerity-minded prime minister - had nonetheless successfully appealed to the EC for budgetary leniency, as he contested a difficult late-June re-election bid. Three days before this re-run for Rajoy, however, a slim majority of British voters shocked EU leaders (and the world) by opting to leave the 28-nation bloc. In Spain, the fallout over the Brexit vote - combined with the budgetary "flexibility" afforded by the EC - translated into a modest increase in the vote share for Rajoy's party, thus ensuring his eventual re-election as prime minister.

In such a context - the disbelief over Brexit, an electoral scare in Spain, and looming populist threats elsewhere in the bloc - the EC had lost its appetite to sanction countries such as Portugal for non-compliance with the supposedly binding budgetary rules that even giants France and Germany break with some frequency. As EU commissioner Pierre Moscovici dexterously put it, "a punitive approach [for Portugal] would not be the right one at a time when people [are doubting the EU]" (cited in Khan and Brunsden 2016).

Given a respite from EU budgetary mandates, the PS-led government began instituting measures to make good on its pledge to end austerity. Under pressure from parliamentary allies BE and PCP, Costa withdrew planned cuts to salaries and pensions, halted the impending privatizations of municipal water and transit authorities, restored some collective-bargaining agreements, and - to popular acclaim - reinstated the four 
lost public holidays. Additionally, his government increased one of Europe's lowest minimum wages and scrapped a suite of regressive tax hikes. These efforts - while limited in scope - resulted, by the end of 2016, in higher domestic demand, consumption, and economic growth. The unemployment rate, too, fell from a high of 16 percent in 2013 to just over 10, and the 2016 budget deficit was cut in half, to 2 percent - a level not seen since the 1970s (Finn 2017: 29; see figure 9). While the above achievements have hardly amounted to a sweeping transformation of Portuguese society, they have nevertheless alleviated some of the hardship experienced by the country's beleaguered middle and working classes from the multiple years of austerity.

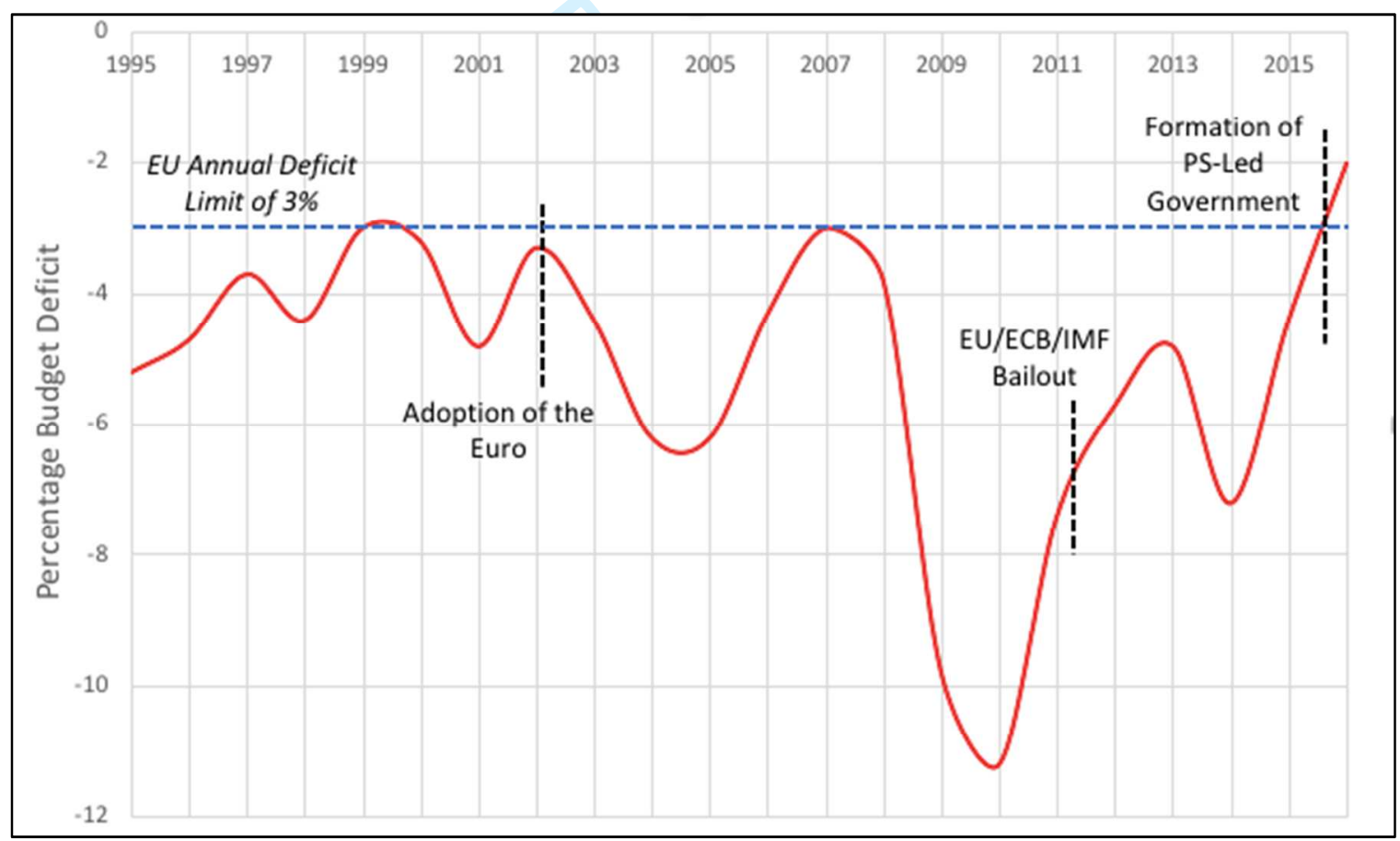

Figure 9 - Portuguese Government Budget Deficit, as Percentage of GDP, 1995-2016 (Source Data: OECD)

This modest recovery notwithstanding, it is an open question as to what will happen to the PS-led government when the next downturn takes place. Threats to this novel three-party accord abound, particularly from external sources. Given that Costa insisted that he would honor EU budgetary constraints, there is little chance of him 
adopting a more radical stance over debt restructuring or demanding a fundamentally different relationship with the Eurozone. In such a context, even a slight change in the country's economic fortunes might make it impossible for the government to satisfy the EU's budgetary mandates without making cuts that would be an anathema to the BE and PCP. An impasse of this kind might then lead the country's international lenders or the credit-rating agencies to simply pull the plug on this unorthodox experiment in center-left/left governance.

\section{Portugal in Ruins}

Some seven years after Portugal received a "rescue" at the hands of international creditors, more than a third of the country's youth are still without work, and debt levels continue to remain among the highest in the Eurozone. Household indebtedness registers at nearly 80 percent of GDP, while public debt amounts to 130 percent and corporate liabilities total more than 140 percent - figures that have all roughly doubled since the mid-2000s (European Commission 2015; cited in Wise 2015). With the economy and tax receipts continuing to register minimal growth, the situation remains neither sustainable nor easily fixed. One possible measure - investment to spur exports among the country's many small- and medium-sized businesses - has been regularly impeded by the large Portuguese banks: four of which have required taxpayer-funded bailouts since 2010, only to be sold later to investors in Spain, Angola, China, and the United States (Martins 2017: 50). In fact, credit for all but the most massive firms is exceedingly difficult to access in Portugal. The remaining major banks are too busy meeting new capital requirements and provisioning against a deluge of loan defaults to be worried about the credit concerns of small businesses and individuals. 
Given Portugal's anemic growth rate, excessively strong currency, "overpriced" goods, and high levels of debt, it is hard to see how the country will be able to avoid some kind of default in the future - an opinion shared by none other than the late Mário Soares, who has previously advocated an "Argentine solution" for its financial obligations (Evans-Pritchard 2013). A more realistic way forward might instead be to formulate a structured "haircut" for Portugal's debt load, though even this modest proposal is unlikely. Among the country's political class, any mention of making the largely foreign lenders bear some responsibility for the loans extended to the national and local governments remains taboo. No Portuguese politician from the three mainstream parties (PS, PSD, and CDS-PP) has spoken seriously of debt forgiveness, for fear of scaring "the markets." Instead, the EU, ECB, and IMF lend their collective institutional weight to ensuring that the Portuguese government repays its creditors in full with interest, no matter how much human suffering occurs in the meantime (Ferreira do Amaral and Louçã 2014). Another potential remedial measure that could temporarily assuage Portugal's troubles would be the creation of "Eurobonds," that is, a supra-state mechanism to equalize the borrowing requirements among all Eurozone countries - both the "lender" nations of Northern Europe and their "borrowing" counterparts in the South. Given the current resistance to Eurobonds among German and Dutch voters and within their countries' ministries of finance, such a proposal would not be politically possible, however rational it may be.

And so continues the political maneuvering, and its attendant crises, bringing little succor to the Portuguese public. The rebuilding of Lisbon after the 1755 earthquake commenced only after the Marquis of Pombal, Sebastião José de Carvalho e Melo, took 
control of the crisis. In his capacity as secretary of state to King José I, Pombal swiftly set about organizing relief and rehabilitation efforts. Firefighters were sent to extinguish the post-earthquake infernos, and scores of workers and ordinary citizens were compelled to dispose of the thousands of corpses to ensure that disease would not spread. To prevent disorder amid the ruins, Pombal deployed the army to prevent able-bodied lisboetas from fleeing the clean-up efforts and sentenced suspected looters to public execution on the gallows.

Pombal did not just take control of the post-earthquake crisis; he also transformed how Lisbon was rebuilt in its aftermath. A little more than a month following the catastrophe, royal engineer Manuel da Maia presented his reconstruction plans for the city to Pombal and the king. Several options were put forward, from widening particular roads to rebuilding the city from the very rubble caused by the earthquake. Da Maia concluded his list by proposing that the entire Baixa neighborhood be razed and that its rebuilding - save the Carmo Covent - should proceed according to a "new plan of boldly designed streets” (França 1989: 18). This daring final option was the one eventually chosen by Pombal and King José I.

Perhaps human-created calamities, such as the one that continues to afflict Portugal and the other countries of the Eurozone periphery, are ultimately more difficult to transcend than those caused by freak natural disasters that take place in eighteenthcentury absolute monarchies. These crises are undoubtedly more difficult to comprehend, and there is always more than enough confusion around to shield those responsible from having to answer for their actions. What is certain, however, is that few people in Portugal can at present show the Portuguese any plausible exit from the current malaise. 


\begin{abstract}
The political class has become structurally incapable of resolving the situation, as it is too focused on domestic political rivalries and the whims of international creditors to address the grave challenges facing the country. Without a reconstruction effort comparable to the one followed by Pombal, it seems as if Portugal will be condemned to a decade or more of high unemployment, sluggish growth, and falling living standards - doomed to remain a minion of German bullying and intransigence.
\end{abstract}

\title{
References
}

Anderson, P. 1962. Portugal and the end of ultra-colonialism. New Left Review 15: 83102.

2009. A new Germany? New Left Review 57: 5-40.

Azevedo, A. P. 2015. Marques Mendes: "um governo de esquerda seria o suicídio de Costa e do PS." Sol, October 10.

Baer, W. and A. P. N. Leite. 1992. The peripheral economy, its performance in isolation and with integration: The case of Portugal. Luso-Brazilian Review 29 (2): 1-43.

Blackburn, R. 1974. The test in Portugal. New Left Review 87/88: 5-46.

Corkhill, D. 2014. The Portuguese economy: The impact of European Monetary Union membership. In Portugal and the European Union: Assessing twenty-five years of integration experience, ed. L. C. Ferreira-Pereira, 43-54. Oxford: Routledge.

Delanty, G. 2014. Perspectives on crisis and critique in Europe today. European Journal of Social Theory 17 (3): 207-18.

European Commission. 2013. The economic adjustment programme for Portugal: Seventh review - winter 2012/2013. Brussels: Directorate-General for Economic and Financial Affairs.

Evans-Pritchard, A. 2013. Portugal's elder statesman calls for an "Argentine-style" default. The Daily Telegraph, April 12.

De Freitas, A. A. 2017. Neoliberalism, profitability, and the crisis in the Eurozone. Review of Radical Political Economics 49 (3): 410-29.

Ferreira do Amaral, J. 2006. O impacto económico da integração de Portugal na Europa. 
Nação e Defesa 115 (3): 113-28.

Ferreira do Amaral, J. and F. Louçã. 2014. Tudo é melhor que 20 anos de protetorado. Expresso, August 30.

Ferreira Borges, S. 2015. Aníbal radical Silva! Contacto, October 28.

Finn, D. 2017. Luso-anomalies. New Left Review 106: 5-32.

França, J. A. 1989. A reconstrução de Lisboa e a arquitectura pombalina. Lisbon: Biblioteca Breve.

Gallagher, T. 1979. Portugal's bid for democracy: The role of the Socialist Party. West European Politics 2 (2): 198-217.

Gonçalves, V. 1976. Entrevista ao Jornal do Brasil. In Discursos, Conferências de Imprensa, Entrevistas. Lisbon: Augusto Paulo da Gama.

Guerreiro, J. F. 2016. Schäuble: "Portugal tem de estar bem ciente de que pode perturbar os mercados." Diário de Notícias, February 11.

Khan, M. and J. Brunsden. 2016. Brussels drops fines against Spain and Portugal for fiscal breaches. Financial Times, 27 July.

Martins, C. 2017. The Portuguese experiment. New Left Review 106: 33-55.

Marujo, M. 2015. Costa: “é como deitar abaixo o resto do muro de Berlim.” Diário de Notícias, October 14.

Meek, J. 2017. Somerdale to Skarbimierz. London Review of Books, April 20.

Minder, R. 2015. Pedro Passos Coelho, who led austerity plan in Portugal, nears reelection. New York Times, October 3.

Morton, A. D. 2011. Review: The Portuguese revolution: state and class in the transition to democracy. Capital \& Class 35 (2): 344-47.

Petmesidou, M. and A. M. Guillén. 2014. Can the welfare state as we know it survive? A view from the crisis-ridden south European periphery. South European Society and Politics 19 (3): 295-307.

Poulantzas, N. 1976. The crisis of the dictatorships: Portugal, Greece, Spain. London: New Left Books.

Público. 2011. Portugal enfrenta dois “anos terríveis," avisa Passos Coelho. June 15. 
Ramos Pinto, P. 2013. Lisbon rising: Urban social movements in the Portuguese
revolution, 1974-75. Manchester: Manchester University Press.

Reis, R. 2013. The Portuguese slump and crash and the Euro crisis. Brookings Papers on Economic Activity (Spring): 143-93.

Rodrigues, J., A. C. Santos, and N. Teles. 2016. Semi-peripheral financialisation: The case of Portugal. Review of International Political Economy 23 (3): 480-510.

Soares, A. G. 2007. Portugal e a adesão às Comunidades Europeias: 20 anos de integração europeia. In España y Portugal: veinte años de integración europea, ed. R. García Pérez and L. Lobo-Fernandes, 63-87. Santiago de Compostela: Tórculo Ediciones.

----------. 2008. Portugal and European Union: The ups and downs in 20 years of membership. Perspectives on European Politics and Society 8 (4): 460-75.

Watkins, S. 2013. Vanity and venality. London Review of Books, August 29.

----------. 2014. The political state of the union. New Left Review 90: 5-25.

Wise, P. 2013. Portugal - waiting it out. Financial Times, May 26.

2015. Portugal divided by austerity. Financial Times, December 1. 